\title{
PENGEMBANGAN ELEKTRODA PASTA KARBON TERMODIFIKASI MIP DENGAN MONOMER ASAM METAKRILAT SEBAGAI SENSOR PADA ANALISIS KREATIN SECARA POTENSIOMETRI
}

\author{
Usreg Sri Handajani*, Cahya Nurrahmi Hidayah Amilianti, Miratul Khasanah \\ Departeman Kimia, Fakultas Sains dan Teknologi, \\ Universitas Airlangga \\ email: usreg-s-h@fst.unair.ac.id
}

Received 16 Oktober 2017

Accepted 28 Nopember 2017

\begin{abstract}
Abstrak
Pada penelitian ini telah dilakukan pengembangan elektroda pasta karbon/MIP untuk analisis kreatin secara potensiometri. Pemilihan teknik imprinting bertujuan untuk membentuk cetakan yang sesuai dengan sisi aktif kreatin pada MIP. Elektroda yang dibuat dari campuran karbon aktif, parafin, dan MIP dengan perbandingan 11:7:2 bagian menunjukkan kinerja optimum. Kinerja elektroda pasta karbon/MIP ditunjukkan oleh nilai faktor Nernst dan linieritas pengukuran yaitu $27,2 \mathrm{mV} /$ dekade dan 0,9915 pada konsentrasi jangkauan pengkuran $10^{-6}-10^{-2} \mathrm{M}$, limit deteksi sebesar $1,1 \times 10^{-6} \mathrm{M}$, akurasi $55-125,8 \%$, dan nilai koefisien variasinya $0,27-0,60 \%$. Elektroda masih memberikan kinerja yang baik hingga pemakaian ke-85. Uji selektivitas terhadap elektroda dilakukan dengan menggunakan matriks glukosa dan menunjukkan hasil bahwa glukosa pada konsentrasi rendah dan normal dalam darah tidak mengganggu analisis kreatin, tetapi glukosa pada konsentrasi tinggi mengganggu proses analisis kreatin.
\end{abstract}

Kata kunci : Elektroda pasta karbon, kreatin, MIP, potensiometri

\begin{abstract}
In this research, carbon paste/MIP electrode has been developed for creatine analysis potentiometrically. Imprinting technique aims to form a mold in accordance with the active site of creatine in MIP. The developed electrode was manufactured from a mixture of activated carbon, paraffin, and MIP with ratio of 11:7:2 parts. The performance of carbon paste/MIP electrode is indicated by Nernst factor values and measurement linearity of 27,2 $\mathrm{mV} /$ decade and 0,9915 respectively at concentration range $10^{-6}-10^{-2} \mathrm{M}$, detection limit was $1.1 \times 10^{-6} \mathrm{M}$, accuracy $55-125,8 \%$ and the coefficient variation of $0,27-0,60 \%$. Electrodes still provide good performance over 85 times usage. Selectivity test on electrode was done by using glucose matrix showing glucose at low and normal concentration in blood did not interfere on creatine analysis, but high concentration of glucose disrupted creatine analysis.
\end{abstract}

Keywords : Carbon paste electrode, creatine, MIP, potentiometry

\section{PENDAHULUAN}

Kreatin adalah asam organik bernitrogen yang berperan penting dalam pembentukan dan pemanfaatan ATP untuk otot, otak, dan jantung (Wallimann et al.,1992; Ardon et al., 2016). Kreatin dapat diperoleh dari sumber makanan seperti daging dan ikan untuk mensintesis ATP untuk cadangan energi (Riesberg et al., 2015).

Dalam dunia industri olahraga kreatin monohidrat diproduksi sebagai suplemen yang dapat menunda kelelahan otot serta menambah masa otot (Perskyi dan 
Brazeau, 2001). Adapun beberapa efek negatif dari mengkonsumsi kreatin secara berlebihan yaitu dapat menyebabkan kram otot, stroke, sesak nafas, hipertensi, rasa cemas, dan masalah pada ginjal (Brudnak, 2004).

Berbagai metode telah digunakan dalam analisis kreatin seperti metode high performance liquid chromatography (HPLC), spektrofotometri, dan voltammetri. Metode HPLC memiliki selektivitas tinggi dan membutuhkan jumlah sampel yang sedikit, namun membutuhkan biaya yang mahal dan waktu yang lama sehingga hanya sesuai untuk analisis yang berkelanjutan (Yokoyama et al., 2000). Analisis kreatin secara spektrofotometri membutuhkan waktu analisis yang lama, sampel yang tidak sedikit, dan membutuhkan pereaksi kimia (Sewell et al., 2002). Lakshmi et al. (2007) melakukan analisis kreatin secara voltammetri menggunakan hanging mercury drop electrode (HMDE) termodifikasi moleculary imprinted polymer (MIP) yang terbuat dari poli(pasam amino benzoat-co-1,2-dikloroetana). Analisis kreatin dengan metode ini memberikan sensitivitas tinggi dan limit deteksi rendah. Namun, analisis kreatin dengan voltammetri tersebut kurang selektif karena masih terganggu oleh kontaminan yang berada dalam sampel seperti histidin dan triptopan. Patel et al. (2010) menggunakan metode voltammetri untuk analisis kreatin melalui modifikasi elektroda menggunakan MIP yang bersifat zwiter ionik dalam sol-gel, meskipun kembali lagi masalah utama terkait kontaminan juga membatasi studi yang dilakukan.

Metode lain yang telah dikembangkan untuk analisis kreatin adalah potensiometri. Metode potensiometri merupakan metode analisis secara elektrokimia yang berdasarkan hubungan antara potensial sel dan aktivitas analit (Tessutti et al., 2013). Perbedaan tegangan potensial antara dua elektroda pada potensiometri diukur dengan mempertahankan arus listrik bernilai nol (Telting-Diaz dan Qin, 2006). Metode ini tidak dipengaruhi oleh reaksi redoks sehingga dapat digunakan untuk analisis senyawa non elektroaktif. Analisis menggunakan metode ini melibatkan prosedur sederhana tetapi memiliki selektivitas dan sensitivitas yang tinggi serta limit deteksi yang rendah (Sahara, 2008), sehingga masalah yang ditimbulkan oleh kontaminan dapat diminimalkan. Penelitian sebelumnya telah mengembangkan metode potensiometri dengan memodifikasi elektroda pasta karbon menggunakan imprinted zeolite sebagai sensor kreatin dan diperoleh limit deteksi atas sebesar $5,53 \times 10^{-5} \mathrm{M}$ dan limit deteksi bawah sebesar $1,3 \times 10^{-8} \mathrm{M}$. Keberadaan urea dalam larutan sampel tidak mengganggu analisis kreatin (Athiroh, 2016).

Pada penelitian ini dilakukan analisis kreatin secara potensiometri menggunakan elektroda pasta karbon termodifikasi molecularly imprinted polymer (MIP). MIP terbuat dari asam metakrilat (MAA) etilen glikol dimetakrilat, dan kreatin dengan perbandingan mol 4:12:1 (Kustyarini, 2016). Pemilihan MAA sebagai MIP untuk memodifikasi elektroda disebabkan MAA menghasilkan polimer yang bersifat rigid (kaku) sehingga dapat mempertahankan bentuk dan ukuran cetakan saat dicelupkan dalam larutan. Hal ini diharapkan dapat meningkatkan kinerja elektroda dan mengurangi kemungkinan adanya interferensi dari senyawa lain dalam analisis kreatin.

Parameter yang dipelajari pada penelitian ini adalah komposisi optimum karbon aktif dan MIP pada pembuatan elektroda termodifikasi MIP, pengaruh $\mathrm{pH}$, dan kinerja elektroda pasta karbon yang telah termodifikasi MIP. Kinerja elektroda pasta karbon termodifikasi MIP yang dipelajari meliputi faktor Nernst, jangkauan pengukuran, limit deteksi, presisi, akurasi, selektivitas, waktu respon, dan waktu hidup elektroda. 


\section{METODE PENELITIAN}

\section{Bahan Penelitian}

Bahan-bahan yang digunakan dalam penelitian ini adalah kreatin, glukosa, asam metakrilat, kloroform, n-heksana, etilen glikol dimetakrilat (EGDMA), benzoil peroksida (BPO), etanol, natrium asetat trihidrat, dinatrium hidrogenfosfat dihidrat, natrium dihidrogenfosfat dihidrat, karbon, parafin padat, kawat Ag, dan akuades.

\section{Alat-alat Penelitian}

Alat-alat yang digunakan dalam penelitian ini adalah seperangkat alat potensiometer, $\mathrm{pH}$-meter, FTIR, corong Buchner, penangas air, pengaduk magnetik, neraca analitik, tip mikropipet $1,00 \mathrm{~mL}$, dan alat gelas yang lazim digunakan di laboratorium.

\section{Pembuatan Molecularly Imprinted Polymer}

Molecularly imprinted polymer (MIP) dibuat dari sebagian non imprinted polymer (NIP) yang diekstraksi. Adapun NIP disintesis dengan mencampurkan asam metakrilat, etilen glikol dimetakrilat, dan kreatin dengan perbandingan mol 4:12:1. Ketiga bahan tersebut dilarutkan dalam $5 \mathrm{~mL}$ kloroform. Selanjutnya kreatin diekstraksi dengan $10 \mathrm{~mL}$ akuades panas sebanyak tiga kali. Padatan yang diperoleh merupakan MIP kemudian dikeringkan pada suhu $\pm 100^{\circ} \mathrm{C}$ dan dikarakterisasi dengan FTIR.

\section{Pembuatan elektroda pasta karbon/MIP}

Elektroda pasta karbon/MIP dibuat dari campuran karbon aktif, parafin, dan MIP yang dipanaskan untuk membentuk pasta. Kawat Ag dipasang dalam tip mikropipet 1 $\mathrm{mL}$ sebagai penghubung antara elektroda dan potensiometer. Dalam tip mikropipet, $1 / 4$ bagiannya diisi campuran karbon aktif, parafin, dan sisanya diisi dengan lelehan parafin. Pada pembuatan elektroda pasta karbon/MIP dilakukan optimasi komposisi sesuai pada Tabel 1.
Tabel 1. Variasi komposisi karbon aktif, parafin, dan MIP dalam pembuatan elektroda pasta karbon/MIP

\begin{tabular}{cccc}
\hline Elektroda & \multicolumn{3}{c}{ Komposisi (bagian) } \\
& $\begin{array}{c}\text { Karbon } \\
\text { aktif }\end{array}$ & Parafin & MIP \\
\hline E1 & 13 & 7 & 0 \\
E2 & 12 & 7 & 1 \\
E3 & 11 & 7 & 2 \\
E4 & 10 & 7 & 3 \\
E5 & 9 & 7 & 4 \\
\hline
\end{tabular}

Kelima variasi elektroda tersebut diatas digunakan untuk mengukur larutan kreatin $10^{-8}-10^{-2} \mathrm{M}$ untuk mengetahui kinerja optimumnya.

\section{Penentuan $\mathrm{pH}$ optimum larutan kreatin}

Optimasi $\mathrm{pH}$ larutan kreatin dilakukan pada variasi $\mathrm{pH} \mathrm{4,} \mathrm{5,} \mathrm{6,} \mathrm{7,} \mathrm{dan} \mathrm{8.} \mathrm{Optimasi}$ $\mathrm{pH}$ larutan diawali dengan mempipet 5,0 mL larutan standar kreatin $10^{-2} \mathrm{M}$ dan 1 $\mathrm{mL} \mathrm{KCl}$ 0,1 M ke dalam 5 labu ukur 50 mL, kemudian ditambahkan 2 mL larutan buffer $\mathrm{pH} 4,5,6,7$, dan 8 secara berturutturut. Pada kelima labu ditambahkan akudes sampai tanda batas, kemudian dianalisis secara potensiometri menggunakan elektroda kerja pasta karbon/MIP dan elektroda pembanding $\mathrm{Ag} / \mathrm{AgCl}$. Dilakukan prosedur yang sama pada larutan standar kreatin $10^{-8}-10^{-3} \mathrm{M}$. $\mathrm{pH}$ optimum larutan kreatin ditentukan dari persamaan regresi kurva linier dengan faktor Nernst (slope) yang mendekati nilai teoritisnya, yaitu $(59,2 / \mathrm{n} \pm 2) \mathrm{mV} /$ dekade.

\section{Penentuan kinerja elektroda dan validasi metode}

Kinerja elektroda dan validitas metode dinyatakan dengan nilai jangkauan pengukuran, faktor Nernst, limit deteksi, waktu respon, akurasi, presisi, dan waktu hidup elektroda.

Jangkauan pengukuran ditentukan dengan membuat kurva antara log konsentrasi larutan kreatin dan potensial elektroda Jangkauan pengukuran ditentukan dari rentang konsentrasi yang memberikan garis linier pada kurva. 
Faktor Nernst dinyatakan dengan slope pada persamaan regresi kurva linier.

Limit deteksi diperoleh dari titik potong garis regresi linier dan non linier dari kurva hubungan antara log konsentrasi larutan kreatin dan potensial elektroda. Harga log konsentrasi limit deteksi diperoleh dengan menarik garis lurus dari titik potong kedua garis ke sumbu $\mathrm{x}$.

Tingkat akurasi ditentukan dengan mengukur potensial elektroda pada larutan kreatin dengan rentang jangkauan pengukuran. Nilai potensial disubtitusikan ke persamaan regresi sebagai nilai $y$, sehingga dari nilai log konsentrasi (x) diperoleh konsentrasi kreatin. Harga akurasi dihitung dari nilai recovery pada persamaan 1 .

$$
\mathrm{R}=\frac{C s p}{K s} \times 100 \%
$$

Presisi ditentukan dengan menghitung nilai simpangan baku (SD) dan koefisien variasi $(\mathrm{KV})$ sesuai dengan persamaan 2 dan 3 .

$$
\begin{aligned}
& \mathrm{SD}=\sqrt{\frac{\sum(x-\bar{x})^{2}}{n-1}} \\
& \mathrm{KV} \frac{S D}{\bar{x}} \times 100 \%
\end{aligned}
$$

Waktu respon elektroda dihitung mulai dari awal pengukuran potensial elektroda hingga memberikan nilai potensial yang konstan.

Waktu hidup elektroda terhitung dari saat pertama kali digunakan untuk pengukuran sampai saat dimana diperoleh kurva standar yang faktor Nernstnya (slope) menyimpang dari nilai $(59,2 / \mathrm{n} \pm 2)$ $\mathrm{mV} /$ dekade.

\section{Uji selektivitas}

Selektivitas dinyatakan dengan nilai koefisien selektivitas $\left(\mathrm{K}_{\mathrm{ij}}\right)$ dan ditentukan menggunakan glukosa sebagai matriks pengganggu. Pada penelitian ini menggunakan metode mached potensial method (MPM). Penentuan diawali dengan pengukuran potensial elektroda dan pembuatan kurva linier log konsentrasi dengan potensial elektroda pada larutan kreatin $10^{-8}-10^{-2} \mathrm{M}$. kemudian pengukuran potensial elektroda pada larutan glukosa $3 \times 10^{-3}, 5 \times 10^{-3}$, $11 \times 10^{-3}$. Nilai potensial elektroda pada larutan glukosa disubtitusikan sebagai y pada persamaan regresi kurva linier log konsentrasi dengan potensial elektroda pada larutan kreatin, sehingga diperoleh nilai x yaitu log konsentrasi matriks. Nilai yang diperoleh disubtitusikan pada persamaan 4 .

$$
\mathrm{K}_{\mathrm{ij}}=\frac{\Delta i}{C j}
$$

$\mathrm{K}_{\mathrm{ij}}$ merupakan koefisien selektivitas, $\Delta i$ adalah anti log konsentrasi matriks pengganggu, dan $C j$ merupakan faktor Nernst hasil pengukuran larutan kerja.

\section{Hasil dan Pembahasan}

Hasil sintesis molecularly imprinted polymer (MIP)

MIP disintesis sebagai bahan untuk memodifikasi elektroda pasta karbon untuk analisis kreatin. Ektraksi kreatin pada NIP bertujuan untuk memutus ikatan kreatin dengan polimer, sehingga diharapkan meninggalkan cetakan berupa sisi aktif dengan ukuran yang sesuai dengan molekul kreatin. Perkiraan posisi kreatin pada NIP dapat dilihat pada Gambar 1 .

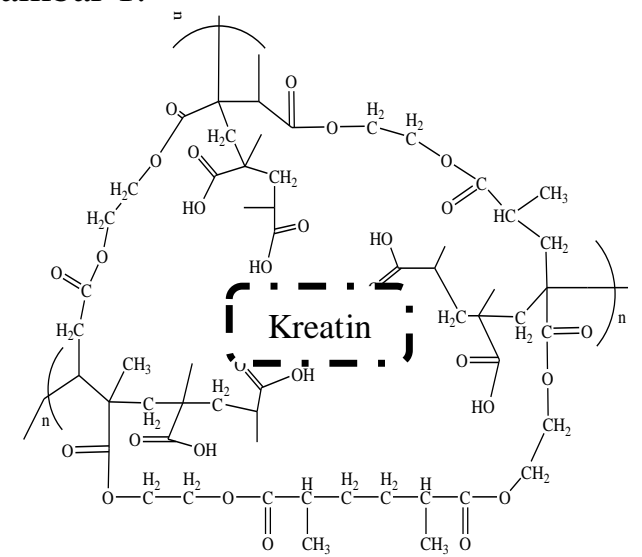

Gambar 1. Perkiraan posisi kreatin pada NIP.

MIP yang terbentuk dikarakterisasi dengan FTIR Untuk mengetahui gugus fungsi yang ada pada MIP. Karakterisasi 
FTIR juga dilakukan pada PMAA dan NIP sebagai pembanding. Hasil karakterisasi FTIR dapat diliat pada Gambar 2 dan Tabel 2.

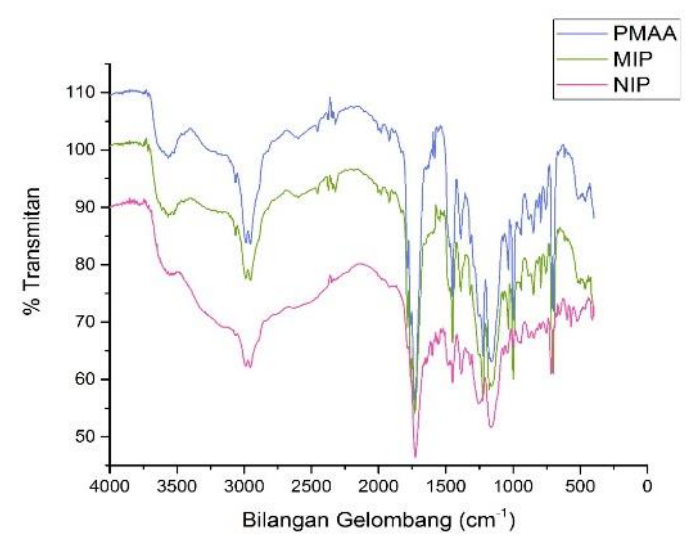

Gambar 2. Spektra FTIR dari MIP (garis Hijau), PMAA (garis biru), dan NIP (garis merah).

Tabel 2. Data bilangan gelombang dari PMAA, NIP, dan MIP

\begin{tabular}{|c|c|c|c|c|c|}
\hline \multirow[t]{2}{*}{ No } & \multirow{2}{*}{$\begin{array}{l}\text { Gugus } \\
\text { fungsi }\end{array}$} & \multirow{2}{*}{$\begin{array}{c}\text { Bilangan } \\
\text { gelombang } \\
\left(\mathrm{cm}^{-1}\right)\end{array}$} & \multicolumn{3}{|c|}{$\begin{array}{l}\text { Bilangan gelomnbang } \\
\qquad\left(\mathrm{cm}^{-1}\right)\end{array}$} \\
\hline & & & PMAA & NIP & MIP \\
\hline 1 & $\begin{array}{l}\mathrm{C}=\mathrm{O} \\
\text { strech }\end{array}$ & $1800-1690$ & 1762,94 & 1726,29 & 1759,08 \\
\hline 2 & $\begin{array}{l}\mathrm{C}=\mathrm{C} \\
\text { strech }\end{array}$ & $1500-1700$ & 1637,56 & 1450,47 & 1598,99 \\
\hline 3 & $\begin{array}{l}\text { N-H } \\
\text { strech }\end{array}$ & $3000-3500$ & 3566,38 & 3552,88 & 3552,88 \\
\hline 4 & $\begin{array}{l}\mathrm{N}-\mathrm{H} \\
\text { bend }\end{array}$ & $1650-1580$ & - & 1600,92 & - \\
\hline 5 & $\begin{array}{l}\mathrm{O}-\mathrm{H} \\
\text { ikatan } \\
\mathrm{H}\end{array}$ & $3300-2500$ & 3062,96 & 3066,67 & 3062,96 \\
\hline 6 & $\begin{array}{l}\mathrm{C}-\mathrm{O} \\
\text { strech }\end{array}$ & $1300-1000$ & 1224,80 & 1257,59 & 1224,80 \\
\hline
\end{tabular}

Hasil Optimasi Komposisi pada Pembuatan Elektroda Karbon/MIP

Penentuan komposisi optimum pada pembuatan elektroda pasta karbon/MIP bertujuan untuk mendapatkan elektroda dengan respon potensial yang baik sehingga dapat menganalisis analit secara maksimal. Pada penelitian ini karbon aktif bertindak sebagai absorben yang bersifat konduktif, parafin sebagai material perekat, dan MIP dengan sisi spesifik analit sebagai material untu memodifikasi elektroda, Kinerja elektroda ditentukan dari faktor Nernst, jangkauan pengukuran, dan linieritas dari kurva antara log konsentrasi kreatin dan potensial yang terukur dari masing-masing elektroda yang dapat dilihat pada Tabel 3 .

Berdasarkan Tabel 3 E3 dipilih sebagai elektroda yang memberikan kinerja optimum karena menghasilkan, jangkauan pengukuran, faktor Nernst dan linieritas yang paling bagus dan mendekati nilai teoritisnya dibandingkan dengan keempat elektroda lainnya

Tabel 3 Nilai faktor Nernst, jangkauan pengukuran, dan linieritas kurva kalibrasi hasil pengukuran kreatin $10^{-8}-10^{-2} \mathrm{M}$ menggunakan elektroda/MIP berbagai variasi komposisi

\begin{tabular}{ccccccc}
\hline Elektroda & $\begin{array}{c}\text { Komposisi (bagian) } \\
\text { Karbon } \\
\text { aktif }\end{array}$ & MIP & parafin & $\begin{array}{c}\text { Faktor } \\
\text { Nernst } \\
(\mathbf{m V / d e k})\end{array}$ & $\begin{array}{c}\text { Jangkauan } \\
\text { pengukuran } \\
(\mathbf{M})\end{array}$ & $\begin{array}{c}\text { Linieritas } \\
(\mathbf{r})\end{array}$ \\
\hline E1 & 13 & 0 & 7 & 20,80 & $10^{-6}-10^{-2}$ & 0,9873 \\
E2 & 12 & 1 & 7 & 9,36 & $10^{-6}-10^{-2}$ & 0,9846 \\
E3 & 11 & 2 & 7 & 26,10 & $10^{-6}-10^{-2}$ & 0,9914 \\
E4 & 10 & 3 & 7 & 11,00 & $10^{-6}-10^{-2}$ & 0,9853 \\
E5 & 9 & 4 & 7 & 16,16 & $10^{-6}-10^{-2}$ & 0,9972 \\
\hline
\end{tabular}

\section{Hasil optimasi pH larutan kreatin}

Elektroda dengan komposisi optimum yaitu E3 digunakan untuk mengukur larutan kreatin pada rentang jangkauan pengukuran $10^{-6}-10^{-2}$ M. Pembuatan larutan kreatin $10^{-6}-10^{-2} \mathrm{M}$ dilakukan dengan penambahan $\mathrm{KCl} 0,1 \mathrm{M}$ bertindak sebagai larutan elektrolit pendukung berfungsi untuk menstabilkan nilai potensial pada saat proses analisis berlangsung.. Hasil pengukuran untuk optimasi $\mathrm{pH}$ pada larutan kreatin $10^{-6}-10^{-}$ ${ }^{2} \mathrm{M}$ dapat dilihat pada Gambar 3 dan Tabel 4.

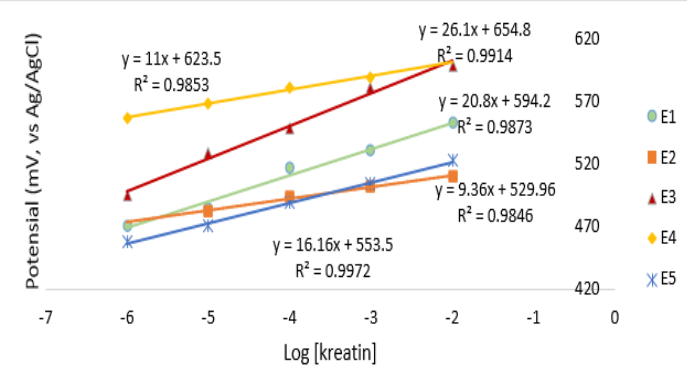

Gambar 3 Kurva hubungan log [kreatin] dan potensial elektroda pada penentuan komposisi optimum

Berdasarkan Tabel 4 elektroda pasta karbon/MIP bekerja secara optimal pada 
$\mathrm{pH}$ 6, Sehingga dapat dikatakan bahwa E3 pada pH 6 merupakan elektroda dengan komposisi dan $\mathrm{pH}$ optimum untuk analisis kreatin.

Tabel 4 Data faktor Nernst, jangkauan pengukuran, dan linieritas dari hasil pengukuran kreatin $10^{-6}-10^{-2} \mathrm{M}$ dengan rentang $\mathrm{pH}$ 4-8 menggunakan E3

\begin{tabular}{cccc}
\hline pH & $\begin{array}{c}\text { Faktor } \\
\text { Nernst }\end{array}$ & $\begin{array}{c}\text { E3 } \\
\text { Jangkauan } \\
\text { pengukuran }\end{array}$ & $\begin{array}{c}\text { Linieritas } \\
(\mathbf{r})\end{array}$ \\
\hline 4 & 12,66 & $10^{-6}-10^{-2}$ & 0,9558 \\
5 & 14,60 & $10^{-6}-10^{-2}$ & 0,9562 \\
6 & 27,04 & $10^{-6}-10^{-2}$ & 0,9904 \\
7 & 17,70 & $10^{-6}-10^{-2}$ & 0,9769 \\
8 & 17,34 & $10^{-6}-10^{-2}$ & 0,9868 \\
\hline
\end{tabular}

Hasil Uji Kinerja Elektroda dan Validitas Metode Analisis

Elektroda dikatakan memiliki kinerja yang baik untuk analisis kreatin apabila memiliki jangkauan pengukuran yang luas dan faktor Nernst yang mendekati 29,5 $\mathrm{mV} /$ dekade. Data potensial elektroda pada pengukuran larutan kreatin $10^{-8}-10^{-2}$ untuk penentuan jangkauan pengukuran dapat dilihat pada Tabel 5, Gambar 4, dan Gambar 5.

Tabel 5. Data potensial elektroda

\begin{tabular}{cc}
\hline Konsentrasi $(\mathrm{M})$ & $\begin{array}{c}\text { Potensial } \\
(\mathrm{mV} \text { vs Ag/AgCl) }\end{array}$ \\
\hline $10^{-2}$ & 835,3 \\
$10^{-3}$ & 806 \\
$10^{-4}$ & 771 \\
$10^{-5}$ & 752 \\
$10^{-6}$ & 726 \\
$10^{-7}$ & 739 \\
$10^{-8}$ & 718 \\
\hline
\end{tabular}

Jangkauan pengukuran dapat dilihat dari rentang konsentrasi yang memberikan garis lurus pada kurva hubungan antara log konsentrasi dengan nilai potensial, serta mendekasi nilai faktor Nernstnya, sehingga jangkauan pengukuran elektroda pasta karbon/MIP pada analisis kreatin adalah $10^{-6}-10^{-2} \mathrm{M}$ dengan faktor Nernst sebesar 27,26 $\mathrm{mV} /$ dekade.
Limit deteksi ditentukan melalui titik potong kurva non-linier dengan kurva linier pada analisis larutan kreatin $10^{-8}-10^{-}$ 2 M. Persamaan kurva linier yang diperoleh dari penelitian ini adalah $\mathrm{y}=$ $27.26 x+887.1$, sedangkan persamaan garis non liniernya adalah $\mathrm{y}=17 \mathrm{x}^{2}+$ 261.2x +952.8 . Perpotongan antara kurva non linier dengan kuva linier dapat dilihat pada Gambar 6.

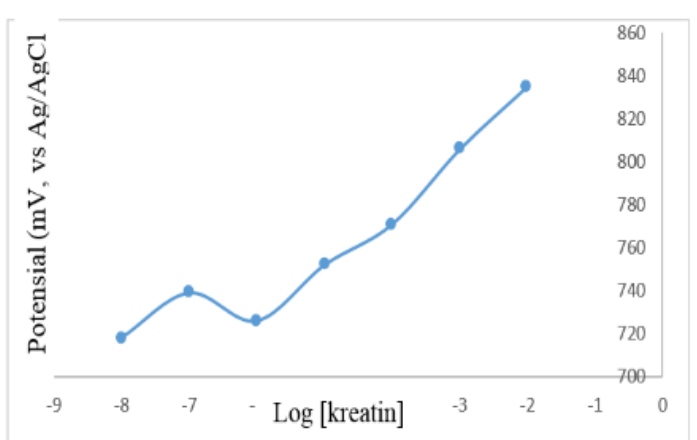

Gambar 4. Kurva hubungan antara log [kreatin] dengan potensial elektroda

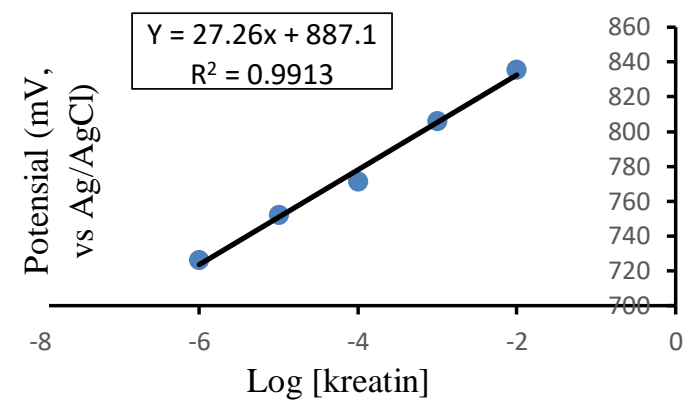

Gambar 5 Kurva standar kreatin

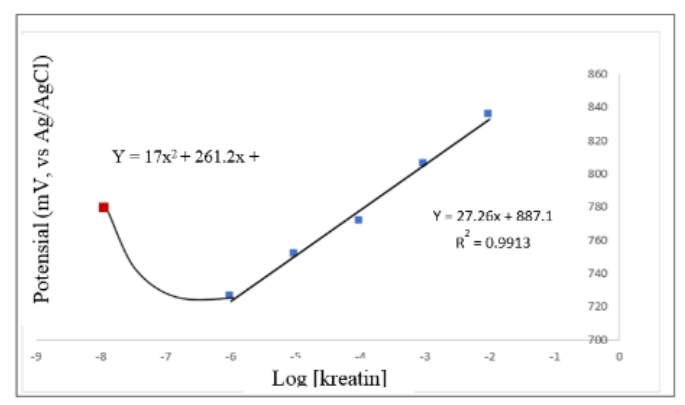

Gambar 6. Kurva hubungan log [keratin] dengan potensial elektroda pada penentuan limit deteksi

Dari regresi kurva non linier dan linier diperoleh limit deteksi sebesar $1,1 \times 10^{-6} \mathrm{M}$. Pada penelitian ini, waktu yang 
dibutuhkan elektroda pasta karbon/MIP dalam merespon kreatin 58 sampai 60 detik. Waktu respon yang diperoleh merupakan waktu yang dibutukan analit untuk mencapai kesetimbangan pada permukaan elektroda.

Akurasi dalam penelitian ini menyatakan ketepatan elektroda sebagai sensor dalam analisis kreatin. Akurasi ditentukan dengan mengukur potensial elektroda pada larutan kreatin pada rentang jangkauan pengukuran yaitu $10^{-6}-10^{-2} \mathrm{M}$ menggunakan E3. Data nilai akurasi hasil analisis kreatin dapat dilihat pada Tabel 6

Tabel 6. Data akurasi hasil analisis kreatin menggunakan E3

\begin{tabular}{ccc}
\hline $\begin{array}{c}\text { Konsentrasi } \\
\text { Sebenarnya } \\
(\mathbf{M})\end{array}$ & $\begin{array}{c}\text { Konsentrasi } \\
\text { Hasil Analisis } \\
(\mathbf{M})\end{array}$ & $\begin{array}{c}\text { Akurasi } \\
(\boldsymbol{\%})\end{array}$ \\
\hline $10^{-6}$ & $1,231 \times 10^{-6}$ & 123,1 \\
$10^{-5}$ & $1,107 \times 10^{-5}$ & 110,1 \\
$10^{-4}$ & $5,508 \times 10^{-5}$ & 55,0 \\
$10^{-3}$ & $1,059 \times 10^{-3}$ & 105,9 \\
$10^{-2}$ & $1,258 \times 10^{-2}$ & 125,8 \\
\hline
\end{tabular}

Berdasarkan Tabel 6 nilai akurasi yang diperoleh selanjutnya dibandingkan dengan batasan menurut Association of Official Analytical Chemist (AOAC). Pada penelitian ini yang memenuhi standar AOAC adalah konsentrasi $10^{-3} \mathrm{M}$, sedangkan pada konsentrasi $10^{-6}, 10^{-5}$, $10^{-4}$, dan $10^{-2} \mathrm{M}$ belum memenuhi nilai standart AOAC (Taverniers et al., 2004).

Tabel 7. Data KV hasil pengukuran kreatin $10^{-6}-10^{-2} \mathrm{M}$ menggunakan E3.

\begin{tabular}{ccccccc}
\hline $\begin{array}{c}\text { Konsentrasi } \\
(\mathrm{M})\end{array}$ & \multicolumn{2}{c}{$\begin{array}{c}\text { Nilai Potensial } \\
(\mathrm{mV}, \mathrm{vsAg} / \mathrm{AgCl})\end{array}$} & $\begin{array}{c}\text { Potensial } \\
\text { Rata-rata }\end{array}$ & $\begin{array}{c}\text { Standar } \\
\text { Deviasi }\end{array}$ & $\begin{array}{c}\text { KV } \\
(\%)\end{array}$ \\
\hline $10^{-6}$ & 721 & 728 & 729 & 726 & 4,36 & 0,60 \\
$10^{-5}$ & 750 & 752 & 754 & 752 & 8 & 0,27 \\
$10^{-4}$ & 768 & 770 & 775 & 771 & 26 & 0,47 \\
$10^{-3}$ & 809 & 804 & 805 & 806 & 14 & 0,3 \\
$10^{-2}$ & 832 & 835 & 839 & 835,3 & 24,67 & 0,42 \\
\hline
\end{tabular}

Presisi dinyatakan dengan nilai koefisien variasi (KV). Taverniers et al., (2004) menyatakan bahwa suatu metode pengukuran dikatakan memiliki ketelitian yang tinggi apabila dari perhitungan diperoleh nilai $<11 \%$ untuk konsentrasi
$10^{-6}-10^{-2}$ M. Data nilai KV hasil pengukuran larutan kreatin $10^{-6}-10^{-2} \mathrm{M}$ dapat dilihat pada Tabel 7

Berdasarkan Tabel 7 nilai KV yang telah memenuhi standart AOAC. Dengan demikian dapat dikatakan elektroda pasta karbon/MIP yang dikembangkan memiliki ketelitian yang baik. Pada penelitian ini waktu hidup elektroda dinyatakan dengan jumlah pemakaian. penentuan waktu hidup elektroda. Data hasil penentuan waktu hidup elektroda dapat dilihat pada Tabel 8 .

Tabel 8. Data jangkauan pengukuran dan faktor Nernst pada penentuan waktu hidup E3

\begin{tabular}{ccc}
\hline $\begin{array}{c}\text { Pemakaian } \\
\text { ke- }\end{array}$ & $\begin{array}{c}\text { Jangkauan } \\
\text { Pengukuran } \\
(\mathbf{M})\end{array}$ & $\begin{array}{c}\text { Faktor } \\
\text { Nernst } \\
\text { (mV/dekade) }\end{array}$ \\
\hline $1-8$ & $10^{-6}-10^{-2}$ & 17,50 \\
$11-27$ & $10^{-6}-10^{-2}$ & 26,60 \\
$30-55$ & $10^{-6}-10^{-2}$ & 27,04 \\
$55-63$ & $10^{-6}-10^{-2}$ & 27,26 \\
$64-74$ & $10^{-6}-10^{-2}$ & 25,20 \\
$75-85$ & $10^{-6}-10^{-2}$ & 18,00 \\
\hline
\end{tabular}

Berdasarkan Tabel 8 elektroda pasta karbon/MIP memberikan penurunan nilai faktor Nernst pada pemakaian ke 64-85, sehingga dapat dikatakan waktu hidup elektroda pasta karbon/MIP yaitu hingga pemakaian ke-85.

\section{Hasil uji selektivitas}

Pada penelitian ini uji selektivitas elektroda untuk analisis kreatin dilakukan dengan menggunakan matriks glukosa pada konsentrasi $3 \times 10^{-3}, 5 \times 10^{-3}$, dan $11 \times 10^{-3} \mathrm{M}$. Pemilihan larutan glukosa disebabkan karena glukosa merupakan molekul dengan konsentrasi yang cukup tinggi dalam darah dan memungkinkan dikenali oleh elektroda karena kemiripan gugus fungsinya dengan kreatin. Elektroda dikatakan selektif terhadap kreatin apabila memberikan nilai $\mathrm{K}_{\mathrm{ij}}{ }^{\text {pot }}<1$. Adapun data hasil selektivitas elektroda dapat dilihat pada Tabel 9.

Berdasarkan Tabel 9 diketahui bahwa E3 selektif terhadap kreatin daripada glukosa pada konsentrasi rendah dan 
normal, namun kurang selektif pada glukosa konsentrasi tinggi dalam darah. Hal ini dimungkinkan semakin pekat konsentrasi glukosa akan berkompetisi dengan kreatin untuk mencapai permukaan elektroda

Tabel 9. Data $K_{\mathrm{ij}}$ hasil perhitungan uji selektivitas elektroda dalam matriks glukosa menggunakan E3

\begin{tabular}{cccccc}
\hline $\begin{array}{c}\text { Konsentrasi } \\
\text { kreatin (M) }\end{array}$ & $\begin{array}{c}\text { Konsentrasi } \\
\text { Glukosa (M) }\end{array}$ & $\begin{array}{c}\text { Nilai } \\
\text { Potensial } \\
(\mathbf{m V})\end{array}$ & $\begin{array}{c}\text { Nilai } \\
\text { Pengukuran } \\
\text { Potensial } \\
\text { rata-rata } \\
(\mathbf{m V})\end{array}$ & $\mathbf{K}_{\mathbf{i j}}{ }^{\text {ot }}$ \\
\hline $10^{-4}$ & $3 \times 10^{-3}$ & 337 & 331 & 334 & \\
$10^{-4}$ & $5 \times 10^{-3}$ & 365 & 369 & 367 & 0,02 \\
$10^{-4}$ & $11 \times 10^{-3}$ & 401 & 402 & 401,5 & 3,24 \\
\hline
\end{tabular}

\section{Kesimpulan}

Komposisi optimum material penyusun elektroda pasta karbon/MIP untuk analisis kreatin secara potensiometri terdiri dari karbon aktif, MIP, dan parafin dengan perbandingan 11:2:7. Adapun $\mathrm{pH}$ optimum larutan kreatin adalah $\mathrm{pH} 6$.

\section{Daftar Pustaka}

Ardon, O., Procter, M., Mao, R., Longo, N., Landau, Y.E., Shilon-Hadass, A., Gabis, L.V., Hoffmann, C., Tzadok, M., Heimer, G., Sada, S., Ben-Zeev, B. and Anikster, Y., 2016, Creatine Transporter Deficiency: Novel Mutations and Functional Studies, Molecular Genetics and Metabolism Reports, $8: 20-23$

Athiroh, A., 2016 Modifikasi Elektroda Pasta Karbon dengan Imprinted Zeolite sebagai Sensor Untuk Analisis Kreatin secara Potensiometri, Skripsi, Fakultas Sains dan Teknologi, Universitas Airlangga

Brudnak, M. A., 2004, Creatine: are the Benefits Worth the Risk, Toxicology Letter, 150 : 123-130

Kustyarini, L., 2016, Pengembangan Elektroda Pasta Karbon / Molecularly Imprinted Polymer (Mip) Dengan Monomer Asam Metakrilat untuk Analisis Glukosa secara Potensiometri, Skripsi, Fakultas Sains dan Teknologi, Universitas Airlangga
Kinerja elektroda pasta karon/MIP untuk analisis kreatin dinyatakan dengan nilai faktor Nernst yaitu sebesar 27,26 mv/dekade dengan linieritas kurva 0,9913 pada jangkauan pengukuran $10^{-6}-10^{-2} \mathrm{M}$. Elektroda pasta karbon/MIP yang dikembangkan memberikan nilai akurasi sebesar 55-125,8\% serta presisi yang dinyatakan dengan nilai $\mathrm{KV}$ sebesar 0,27 $0,6 \%$. Waktu respon elektroda pasta karbon/MIP adalah 58-66 detik dan dapat digunakan hingga pemakaian ke-85. Uji selektivitas elektroda menghasilkan nilai $\mathrm{K}_{\mathrm{ij}}<1$ pada konsentrasi rendah dan normal glukosa dan $\mathrm{K}_{\mathrm{ij}}>1$ pada konsentrasi tinggi.

\section{Saran}

Adanya penelitian lanjutan yang mempelajari pengaruh matriks selain glukosa terhadap analisis kreatin dan tentang aplikasi elektroda pasta karbon/MIP untuk analisis kreatin pada sampel darah

Lakshmi, D., Prasad, B.B. and Sharma, P.S., 2007, Imprinted Polymer Modified Hanging Mercury Drop Electrode for Differential Pulse Cathodic Stripping Voltammetric Analysis of Creatine, Biosensor and Bioelectronics, 22 : 3302-3308

Patel, A.K., Sharma, P.S. and Prasad, B.B., 2010, Trace-Level Sensing of Creatine in Real Sample Using A Zwitterionic Molecularly Imprinted Polymer Brush Grafted to Sol-Gel Modified Graphite Electrode, Thin Solid Films, 518 : 2847-2853

Perskyi, A.M. and Brazeau, G.A., 2001, Clinical Pharmacology of the Dietary Supplement Creatine Monohydrate, Pharmacological Reviews, 53:161176

Riesberg, L.A., Weed, S.A., McDonald, T.L., Eckerson, J.M. and Drescher, K.M., 2015, Beyond Muscles: The Untapped Potential of Creatine, International Immunopharmacology, 1-12 
Sahara, E., 2008, Penentuan $\mathrm{Cu}, \mathrm{Pb}, \mathrm{Cd}$, dan Zn Dalam Air Secara Stripping Potentiometri dengan Elektroda Konvensional dan Kombinasi, Jurnal Kimia, 2 : 105-110

Sewell, A.C., Murphy, H.C. and Iles, R.A., 2002, Proton Nuclear Magnetic Resonance Spectroscopic Detection of Sialic Acid Storage Disease, Clinical Chemistry, 48 : 357-359

Taverniers, I., Loose, M. D., dan Bockstaele, E. V., 2004, Trends in Quality in the Analytical Laboratory. II. Analytical Method Validation and Quality Assurance, Trends in Analytical Chemistry, $23: 1-8$

Telting-Diaz, M., and Qin, Y., 2006, Potentiometry, Comprehensive Analytical Chemistry, 47: 625-659

Tessutti, L.S., Macedo, D.V., Kubota, L.T., and Alves, A.A., 2013, Measuring The Antioxidant Capacity of Blood Plasma Using Potentiometry, Analytical Biochemistry, 441 : 109-114
Wallimann, T., Wyss, M., Brdiczka, D.,Nicolay, K., and Eppenberger, H.M., 1992, Intracellular Compartmentation, Structure and Function of Creatine Kinase Isoenzymes in Tissues with High and Fluctuating Energy Demands: The 'Phosphocreatine Circuit' for Cellular Energy Homeostasis, Journal of biochemistry, $281: 21-40$

Yokoyama, Y., Horikoshi, S., Tukahashi, T., and Sato, H., 2000, Low Capacity Cation Exchange Chromatography of Ultraviolet-asorbing Urinary Basic Metabolites Using a Reserved Phase Column Coated with Hexadecysulfonate, Journal Chromatography A, 886 : 297-302 